\title{
Tyskland tyve år efter
}

\section{Jan Bo Hansen}

\section{Ved tyveåret for Murens fald er såvel frygten for et dominerende som forventningerne til et handle- kraftigt Tyskland gjort til skamme}

Forbundsdagsvalget den 27. september faldt (næsten) sammen med tyveåret for Murens fald i Berlin. Dette noget skæve jubilæum er blevet fejret med alle midler: Den samlede mediepark er blevet indsat for at mindes begivenhederne, der ledte op til faldet. Hver aften sender fjernsynet sine gamle strimler, Erich Honecker og Mikhail Gorbatjov toner frem på skærmen og fremsiger deres velkendte soundbits. Om fem år vil det bryde ud igen.

Valgresultatet fik det til at ligne en tanke, et skel i den politiske historie: Socialdemokratiets tilbagegang med 12 procentpoint til 23 procent er ikke bare den største tilbagegang i partiets historie, det er den største tilbagegang, noget parti har oplevet ved et enkelt valg efter krigen. CDU og det liberale parti FDP vil nu danne regering, mens SPD må række sig ind blandt oppositionspartierne som et af tre, der nu vil kappes om at fremvise en alternativ profil. Fempartisystemet er kommet for at blive.
Det er et volatilt system, og næste gang vil andre partier blive ramt. Men denne gang var det altså SPD.

Det er en fortsættelse af tendensen væk fra folkepartierne og i retning af et opsplittet partisystem som det danske. Også CDU gik tilbage. Det drejer sig ganske vist kun om 1,4 procentpoint til 33,8 procent, efter socialdemokratisk målestok et misundelsesværdigt resultat. Men det er alligevel det næstdårligste $\mathrm{i}$ partiets historie. Antallet af kernevælgere skrumper $i$ alle partierne. FDP, der med 14,6 procent har haft det bedste valg i partiets historie, har samtidig en meget lille gruppe af kernevælgere. Det kræver ikke ikke særlige evner at spå partiet en kraftig tilbagegang i 2013.

Partierne vil skulle bevæge sig. Det er allerede sket med dannelsen af en delstatsregering bestående af CDU og De Grønne i Hamburg, et eksperiment, der vil blive fulgt med interesse i de øvrige delstater og af CDU's forbundsledelse, hvor man 
ikke har noget imod et alternativ til FDP som regeringspartner.

SPD vil ikke længere på forhånd tage afstand fra en regeringsdannelse med Die Linke (tidligere PDS).

Men at denne udvikling ikke går $\mathrm{i}$ én retning, ser man i disse dage i Thüringen, hvor SPD har kunnet vælge mellem at danne regering med CDU og Die Linke, og har valgt CDU. Der er to poler i det politiske system - CDU og SPD - men mulighederne for at danne regering er blevet forøget med nye varianter, og partierne vil ikke på forhånd give afkald på bestemte kombinationer.

Det manglende magtperspektiv var den væesentligste årsag til Socialdemokratiets nederlag. SPD havde ved at udelukke en regering med Die Linke fraskrevet sig muligheden for at udgøre et regeringsalternativ til CDU. Det bedste, den socialdemokratiske ledelse kunne håbe på, var at blive juniorpartner i en regering Merkel. Med det perspektiv kunne partiet ikke mobilisere sine vælgere, og mobiliseringen har altid været SPD's achilleshæl. Partiets vælgere gik kun i mindre grad til andre partier. Den største gruppe blev hjemme og bidrog kraftigt til den lave valgdeltagelse på 72 procent.

At der kan dannes et alternativ til den siddende regering vil også $\mathrm{i}$ 2013 være en forudsætning for, at SPD kan mobilisere sine vælgere. Den kommende periode vil utvivlsomt blive brugt på underhåndsforhandlinger med De Grønne og
Die Linke for at sikre de kompromiser i udenrigs- og sikkerhedspolitikken, der er en forudsætning for regeringsdannelsen. Det lægger et stort pres på Die Linke, der spænder fra pragmatisk venstrefløj til stalinistisk ortodoksi.

\section{Merkel II}

Er regeringen Merkel II så dette opbrud til nye bredder, som kredse i FDP taler om, og oppositionen fremmaner i dystre billeder? For omverdenen er der to spørgsmål: Hvad vil det betyde for Tysklands udenrigspolitik, og hvad vil det betyde for den økonomiske politik.

Da DDR for tyve år siden gik ind i Forbundsrepublikken var der store forventninger og skrækscenarier: I det netop udsendte værk med dokumenter fra det britiske udenrigsministerium 1989 og 1990 kan man følge skrækscenarierne, som de udmales i London. Tyskland vil ikke holde sig inden for de grænser, der nu er afstukket med de to staters arealer, men rask gribe ud efter grænserne fra 1937, profeterede Margaret Thatcher. EU vil blive domineret fra Berlin, de østeuropæiske stater vil omgående miste deres nyvundne selvstændighed til tyskerne, Europas japanere. Den bagved liggende holdning er, at tyskernes økonomiske effektivitet og arbejdsvilje er så overvældende, at de vil nedkæmpe enhver modstand og underlægge sig ethvert landområde, 
der åbnes for markedsøkonomien.

På den tyske side var der forventninger til, at Berliner-republikken på en ganske anden måde end Bonn-republikken ville være i stand til at løse de problemer, som den gamle Bonn-republik vaklede under. Disse forventninger fik deres mest prægnante udtryk i Johannes Gross' bog Begründung der Berliner Republik fra 1995. Berlin-republikken kan ikke blive en partistat på samme måde, som Bonn-republikken til borgernes fortrydelse er blevet det, profeterede Gross. Partierne hørte tilsyneladende ikke hans manende ord, for de mekanismer, der styrer det politiske liv i Berlin-republikken synes ganske lig de mekanismer, der styrede Bonn-republikken.

Den økonomiske politik vil være præget af finanskrisen og dens eftervirkninger. Det vil være overordentligt vanskeligt at gennemføre de skattelettelser, to af regeringspartierne, CSU og FDP, i umisforståelige vendinger har lovet deres vælgere. Den første opgave for Merkel II bliver at fremstille en konstruktion, der kan serveres som skattelettelse samtidig med, at man sikrer sig et uændret statsligt provenu.

På længere sigt kæmper Forbundsrepublikken også med omkostningerne ved at integrere det tidligere DDR. Solidarpakt II udløber i 2019, men også efter den dato vil det være nødvendigt at overføre store beløb til de østlige provinser. På endnu længere sigt tynges republikken af de grundlæggende problemer, der hænger sammen med den demografiske udvikling og vanskelighederne ved at opretholde en arbejdsstyrke på et niveau, der kan sikre de kommende pensioner. Det er problemstillinger, der ligger bag forhøjelsen af pensionsalderen fra 65 til 67 år, men i øvrigt er forsvundet fra den offentlige diskussion.

Det ironiske er, at forbundsregeringen i 1990 var meget ubekymret, når det gjaldt opbygningen af det tidligere DDR og til gengæld meget bekymret for de løfter, Helmut Kohl havde givet Sovjetunionen. I sidste instans kom udgifterne til Sovjetunionen/Rusland til at udgøre en meget lille del af udgifterne til opbygningen af DDR - som til gengæld har kostet summer, ingen havde drømt om.

\section{Håb og frygt}

Ved tyveåret kan det konstrateres, at hverken frygt eller håb blev realiseret. Forventningerne til en anderledes handlekraftig regering er blevet skuffet. Frygten for et dominerende Tyskland, der fra Berlin dominerede Øst- og Centraleuropa, mens de små naboer dukkede deres arme hoveder, er gjort til skamme. Der er hverken tegn på det ene eller andet. Gerhard Schröder lagde ud med en kraftig betoning af de tyske interesser - og en betoning af det opbrud, som hans regering udgjorde. Men det varede ikke længe. Væsentlige 
kræfter i det tyske erhvervsliv med stærke interesser i EU satte sig for at forklare Schröder, hvordan EU fungerer, og hvad de tyske interesser i den henseende er. De havde held med sig og blev hjulpet af Schröders facon, der skabte modstandere og kritikere i rask tempo.

Da Angela Merkel kom til, var tilfredsheden stor, i det mindste hos Tysklands naboer mod øst. Det tyske EU-formandskab var præget af viljen til kompromis - hvad der var så meget lettere, som Gerhard Schröder ved sin fremhævelse af de tyske interesser havde trukket uviljen ned over sit syndige hoved. Det lykkedes Merkel at forbedre forholdet til de østeuropæiske stater i den grad, at de i dag snarere udgør det største problem for den europæiske integration. De østeuropæiske stater bremser den europæiske integration, splitter den i udenrigspolitisk henseende og betragter i det hele taget EU som en subventionskilde. Til gengæld er det tyske forhold til Rusland blevet forværret.

\section{EU er lammet}

Den tilbageholdende linje tjener utvivlsomt til at fremme Angela Merkels popularitet blandt de ny medlemslande. Men for EU har det ikke været uden konsekvenser. Den nuværende lammelse skyldes ganske vist ikke den tyske regering, men det virker på den anden side ikke, som om den er uvelkommen. Det står klart, at intiativer til en mere effektiv union skal komme fra Tyskland og Frankrig. Fra Nicolas Sarkozy kan man ikke forvente dem, i hvert fald ikke initiativer med henblik på kerneområderne. Frankrig har lagt kræfter i Middelhavsunionen, og i det andet hjørne af Europa organiserer landene ved Østersøen sig. Det er alt sammen organisering af de utilfredse med henblik på at sikre sig en større del af kagen. Men det er ikke noget, der bringer EU fremad.

Om det overhovedet er muligt for Frankrig og Forbundsrepublikken at bevæge den nu så kraftigt udvidede Europæiske Union, på samme måde, som det er sket tidligere, er et andet spørgsmål. Det er tænkeligt, at de tider er forbi, hvor det kunne lade sig gøre, og at EU falder fra hinanden eller i hvert fald tilbage i en tilstand af ubevægelighed. Den masse, der skal bevæges, er blevet så meget større end de bevægende kræfter, at selv den mest energiske politiske ledelse i Frankrig og Forbundsrepublikken ville have vanskeligt ved at skabe ny bevægelse. Til de mest energiske kræfter, når det gælder EU, kan man næppe regne Angela Merkel. I den sidste halvdel af Merkel I har der ikke været forsøg i den retning. Det kræver en høj grad af optimisme at forvente dem i Merkel II.

Jan Bo Hansen, Tysklandsekspert og journalist på Weekendavisen. 